\title{
UMBATRA
}

Indonesian Journal of Anthropology

Volume 4 (1) Juli 2019 || eISSN 2528-1569 | pISSN 2528-2115 || http://jurnal.unpad.ac.id/umbara

DOI : 10.24198/umbara.v4i1.19039

\section{Pemberdayaan Sosial dan Ekonomi pada Kelompok Penyandang Disabilitas Fisik di Kota Bandung}

\author{
Ariel Pandita Dhairyya ${ }^{1}$, Erna Herawati ${ }^{2}$ \\ ${ }^{1}$ Program Studi Sarjana Antropologi, FISIP, Universitas Padjadjaran \\ arielpanditad@gmail.com \\ ${ }^{2}$ Departemen Antropologi, FISIP, Universitas Padjadjaran
}

\begin{abstract}
This study explores an economic and social empowerment activities by Kelompok Berani Binangkit (KBB), an informal organization for the people with disabilities in Bandung City. KBB activities focus on pegleg and pegarm production and selling to improve the members's livelihood. KBB also has mission to donate pegleg and pegarm for the disabled who could not affort it. All of the KBB activities are initiated by the members. The study applies qualitative method; in particular case study model. Data were collected through participation observation towards KBB's activities and in-depth interviews to its members. The study finds that the main purpose of $\mathrm{KBB}$, that is to improve the livelihood of the members has not brought a significant impact to its members. The members' income is relatively small and does not sufficient for their living. Meanwhile social empowerment activities has brought a significant impact to the member's social lives. The KBB members build an emotional bond throught several ways such as spesific model of communication among them, and build self confidence as well as develop open-minded attitude regarding their physical condition and response towards negative stigma that attached to them. These have led KBB's members construct their new identity, so they could feel 'normal'.
\end{abstract}

Keywords: Economic, Social, Empowerment, Disability

\begin{abstract}
Abstrak
Penelitian ini mengenai kegiatan pemberdayaan ekonomi dan sosial di Kelompok Berani Binangkit (KBB) di Kota Bandung yang mayoritas anggotanya adalah penyandang disabilitas fisik. Kegiatan utama di kelompok ini adalah produksi kaki tangan palsu. Kelompok ini menjadi wadah kegiatan pemberdayaan ekonomi dan sosial bagi para anggotanya. Penelitian ini menggunakan desain kualitatif dengan model studi kasus. Teknik pengumpulan data dilakukan dengan cara pengamatan terlibat pada seluruh kegiatan KBB, dan wawancara mendalam pada para anggotanya. Hasil penelitian ini menunjukkan hasil kegiatan pemberdayaan ekonomi belum memberikan dampak yang signifikan pada ekonomi rumah tangga para anggota. Namun, pemberdayaan sosial justru memberikan dampak yang sangat besar bagi kehidupan sosial para anggota. Ikatan emosional, komunikasi yang unik antar anggota, berdampak pada terbentuknya kepercayaan diri para anggota. Hal itu mendorong mereka
\end{abstract}


memiliki pemikiran yang terbuka dalam menyikapi kondisi fisiknya dan merespon stigma negatif mengenai penyandang disabilitas fisik di masyarakat. Para anggota pun mampu membangun identitas sosial yang lebih kuat di masyarakat yaitu sebagai penyandang disabilitas yang berdaya, dan mereka merasa sebagai orang 'normal'.

Kata kunci : Ekonomi, Sosial, Pemberdayaan, Disabilitas

\section{Pendahuluan}

Penelitian mengenai kaum disabilitas di Indonesia sangat penting dilakukan karena menurut data survey sosial ekonomi nasional (Susenas) oleh Badan Pusat Statistik pada 2012 jumlah penyandang disabilitas di Indonesia saat ini cukup signifikan. Selain itu kebijakan pemerintah mengenai pemberdayaan dan pemenuhan hak kaum disabilitas terutama dalam hal mata pencaharian belum terpenuhi.

Beberapa penelitian mengenai pemberdayaan kelompok disabilitas di Indonesia pernah dilakukan. Gaffara, Riyono, dan Setyawati (2017) meneliti kegiatan pemberdayaan ekonomi bagi kelompok penyandang disabilitas mental dan grahita di Desa Karangpatihan yang diprakasai pemuda karang taruna di desa setempat. Kegiatan itu berupa budidaya ikan lele dan produksi kerajinan keset. Penelitian lain dilakukan oleh Rodiah (2014) di Yayasan Wisma Cheshire Jakarta Selatan. Kegiatan pemberdayaan yang diteliti berupa pembinaan keterampilan membuat kerajinan tangan dan kerajinan kayu bagi penyandang disabilitas fisik. Setelah berada di yayasan selama 1-2 tahun untuk mengikuti kegiatan pembinaan, para penyandang disabilitas kembali kepada ma-syarakat untuk menerapkan keterampilan yang dimilikinya. Kegiatan pemberdayaan disabilitas yang diparakarsai oleh disabilitas sendiri, diteliti oleh Widiantoro, Wartono, dan Sinta (2016). Kegiatan pemberdayaan dilakukan di Yogyakarta berupa bisnis madu. Usaha madu telah berlangsung selama 10 tahun dan cukup sukses dalam penjualannya melalui offline dan online. Hasil dari penelitian-penelitian itu menunjukkan bahwa kegiatan pemberdayaan itu sangat membantu para penyandang disabilitas untuk mengasah keterampilan mereka dan menghasilkan pendapatan finansial, meskipun jumlahnya belum mampu memenuhi seluruh kebutuhan ekonomi rumah tangga

Penelitian mengenai pemberdayan kaum disabilitas di Indonesia memang telah banyak dilakukan, akan tetapi kebanyakan penelitian tersebut menyoroti proses produksi komoditas umum yang dijual pada masyarakat umum. Penelitian ini menyoroti kegiatan pemberdayaan melalui produksi komoditas yang hanya digunakan oleh sesama penyandang disabilitas, yaitu kaki dan tangan palsu. Kelompok Berani Binangkit (KBB) di Kota Bandung memiliki usaha produksi kaki dan tangan palsu yang dipasarkan dengan harga terjangkau. KBB tidak hanya bertujuan memperoleh profit dari usaha mereka, tetapi mereka juga memiliki tujuan charity bagi sesama penyandang disabilitas fisik. Kaki dan tangan palsu produksi KBB dibuat dari bahan yang murah sehingga harganya pun jauh lebih murah dari produk yang diproduksi oleh pabrik.

\section{Kajian Pustaka}

\section{Definisi Disabilitas}

Disabilitas adalah istilah resmi sejak 2016 yang digunakan untuk menggantikan istilah penyandang cacat. Istilah 'penyandang cacat' terkesan diskriminatif, sebab terminologi "cacat" merujuk kepada manusia yang gagal $^{1}$. Pada 2010, sebuah semiloka dalam rangka mendorong Ratifikasi² CRPD (Con-

\footnotetext{
${ }^{1}$ Manusia gagal merujuk pada arti manusia tidak memiliki potensi untuk melakukan sesuatu, padahal halangan disabilitas dapat dikelola dan dihadapi.

${ }^{2}$ Ratifikasi adalah salah satu bentuk pengesahan, yaitu perbuatan hukum untuk mengikatkan diri pada suatu per-
} 
vention on the Rights of Persons with Disabilities) $)^{34}$ menghasilkan kesepakatan untuk mengubah istilah 'penyandang cacat' menjadi penyandang disabilitas. Merujuk hasil semiloka itu, pada 19 - 20 Maret 2010, Komnas HAM pun secara formal mengganti kata "penyandang cacat" menjadi "disabilitas".

Pada 26 Mei 2015, sebuah FGD (focus group discussion) digelar oleh Kementerian Sosial di Balai Besar Rehabilitasi Sosial Bina Daksa (BBRSBD), dan dihadiri oleh peserta yang berkecimpung dalam topik disabilitas, seperti Pusat Pengembangan dan Latihan Rehabilitasi Para Cacat Bersumberdaya Masyarakat (PPRBM). Di dalam FGD tersebut, para peserta mengkritisi penggunaan kata disabilitas karena konotasi "dis" yang bermakna negatif. Disabel (disable) mengacu kepada "keterbatasan". Mereka menyarankan penggunaan istilah difabilitas atau difable yang merupakan singkatan dari different ability atau memiliki "kemampuan berbeda". Istilah ini dianggap lebih tepat digunakan karena berkonotasi lebih positif dan ramah (Utomo, 2015). Namun, istilah tersebut tidak disepakati.

Pada 2016, Undang-undang No.8/ 2016 terbit dan menggunakan istilah disabilitas, bukan difabilitas, untuk mendefinisikan orang yang mengalami keterbatasan fisik, intelektual, mental, dan sensorik dalam jangka waktu lama; sehingga mengalami hambatan dalam berinteraksi dengan lingkungan sosialnya serta dalam berpartisipasi secara penuh dan efektif dengan warga negara lainnya Sejak terbitnya undang-undang itu, istilah penyandang disabilitas digunakan sebagai istilah resmi menggantikan istilah difabilitas.
Istilah disabilitas menawarkan wacana lebih bijak, karena menempatkan orang yang memiliki hambatan sementara maupun permanen dalam menjalankan keseharian mereka dalam perspektif luas dan luwes serta menghargai kemanusiaan seseorang, termasuk di dalamnya ibu hamil, anak-anak, lanjut usia, pengguna kursi roda, tunanetra, tunarungu, tunadaksa, dan sebagainya. Penggunaan istilah disabilitas juga ditunjukan untuk memahami adanya keberagaman dan menghargai tingkat kemampuan antara satu orang dan lainnya (Mujimin, 2007).

\section{Stigma sosial penyandang disabilitas}

Dari masa ke masa, persoalan penting yang dihadapi para penyandang disabilitas adalah stigma sosial. Stigma adalah ciri fisik dan sosial yang sifatnya negatif dan mengurangi kualitas identitas sosial dan harga diri seorang individu atau kelompok (Goffman, 1963). Stigma dapat muncul dari luar diri (enacted/ public stigma), diberikan oleh orang lain pada seorang individu atau kelompok; dan dapat pula muncul dari dalam diri (self-stigma). Anggapan warga masyarakat bahwa kaum disabilitas itu lemah dan tidak berdaya adalah contoh dari public/enacted stigma; dan anggapan kaum disabilitas bahwa diri mereka sendiri lemah dan tidak berdaya (padahal tidak demikian) adalah contoh dari self-stigma.

Haidar (2012) mengemukakan bahwa stigma pada disabilitas muncul karena kurangnya pengetahuan masyarakat mengenai disabilitas dan kuatnya paham di masyarakat mengenai pemikiran tradisional, yaitu cenderung mengaitkan disabilitas dengan hal-hal magis dan negatif. Misal anggapan masyarakat bahwa disabilitas merupakan akibat dari kutukan turun-temurun. Berbeda dengan Haidjanjian internasional (Pasal 1 angka 2 UU No. 24 Tahun 2000 tentang Perjanjian Internasional (“UU No. 24/2000")) ${ }^{3}$ Convention on The Rights of Persons with Disabilities (CRPD) merupakan Konvensi Internasional Hak-Hak Penyandang Cacat yang disahkan oleh Majelis Umum Perserikatan Bangsa-Bangsa (PBB) pada sidang ke-61 tanggal 13 Desember 2006, usaha menuju pemenuhan hak asasi manusia kaum Disabilitas

${ }^{4}$ Semiloka diprakasai oleh Komisi Nasional Hak Asasi Manusia (Komnas HAM) dan Departemen Sosial dan dihadiri oleh para pakar (linguistik, sosial budaya, hukum, HAM, psikologi), perwakilan instansi pemerintah, pemerhati penca (penyandang cacat), LSM, serta masyarakat umum 
ar (2012), Sinulingga (2015) menyatakan bahwa stigma pada kaum disabilitas muncul karena masyarakat selalu mengacu kepada paham 'normalisme'. Paham ini menganggap disabilitas sebagai abnormalitas dan dampaknya seringkali berujung pada anggapan bahwa kaum disabilitas adalah kaum abnormal dan obyek yang layak dikasihani, diberi donasi, serta tidak dapat mandiri. Kedua pendapat diatas menegaskan betapa stigma pada penyandang disabilitas sangat langgeng di masyarakat.

Beberapa penelitian menemukan bahwa stigma sosial pada disabilitas berdampak serius pada derajat kesejahteraan dan keberdayaan mereka. Rahman (2008) menemukan bahwa implikasi stigma pada kelompok disabilitas berdampak pada perkembangan psikologis kaum disabilitas, dan juga terbatasnya pemenuhan akses-akses sosial mereka di dalam kehidupan sehari-hari. Anggapan umum bahwa para disabilitas tidak mampu bekerja secara maksimal telah membatasi bahkan menutup akses para disabilitas pada kesempatan memperoleh penghidupan. Dampak stigma sosial pada disabilitas dalam skala lebih luas lagi dapat terlihat pada tidak dilibatkannya mereka dalam pembangunan serta munculnya self-stigma pada para disabilitas yang ditunjukkan oleh hilangnya rasa percaya diri dan munculnya sifat minder mereka saat menghadapi dunia luar (Corrigan, 2004).

Stigma pada disabilitas memang ditemui hampir di setiap masyarakat. Namun demikian, telah tampak pula upaya masyarakat untuk mengurangi stigma sosial itu dan meningkatkan penerimaan sosial pada disabilitas. Lestari dan Luthfiana (2012), pada penelitiannya di Desa Bengkala, menemukan bahwa disabilitas dan non-disabilitas dapat berbagi tempat didalam satu lingkungan yang sama. Di Bengkala, Orang Kolok (istilah lokal bagi orang dengan disabilitas ketulian) dan orang Inget (istilah lokal untuk orang normal) hidup bersama. Orang Kolok mendapatkan peluang pendidikan dan pekerjaan yang sama dengan orang Inget.

Gejala penerimaan sosial pada disabilitas juga nampak meningkat di lembaga pendidikan. Penelitian Muntaz dan Rahmawati (2015) di Sekolah Inklusi menemukan bahwa orang tua murid anak dengan disabilitas dan non-disabilitas tidak berkeberatan jika anakanak mereka berada dalam kelas yang sama. Justru, mereka beranggapan bahwa keragaman perbedaan fisik, atau mental, membuat anak mengenai dan menghargai perbedaan.

Di tingkat pendidikan tinggi, salah satu universitas di Yogyakarta pun mulai merintis Pusat Studi dan Layanan Disabilitas (PSLD), dengan beberapa dosen Program Studi Kesejahteraan Sosial sebagai inisiator. PSLD merupakan layanan khusus bagi mahasiswa disabilitas, khususnya pemenuhan aksesibilitas dalam pendidikan, baik yang media belajar atau arsitektural. Dengan demikian, dapat disimpulkan bahwa stigma sosial masyarakat pada disabilitas memang cukup besar, tetapi di sisi lain beberapa warga masyarakat telah mulai berupaya untuk mengurangi stigma itu.

Pengurangan stigma pada disabilitas, akan memberikan peluang bagi mereka untuk mencegah self-stigma, mengembangkan kemandirian, serta menumbuhkan kepercayaan diri. Sebab, individu yang percaya diri memiliki sikap yang positif terhadap diri sendiri. Rasa percaya diri bukanlah sifat yang diturunkan (bawaan), melainkan diperoleh dari pengalaman hidup, diajarkan dan ditanamkan melalui pendidikan ataupun cara lain. Kepercayaaan diri memungkinkan individu berkembang, berdaya, dan mandiri (Taylor, 1986 dan Lauster, 1978 dalam Siska et al, 2003).

\section{Pemberdayaan Sosial dan Ekonomi Disabili- tas}

Intervensi yang dilakukan pemerintah melalui aneka program pemberdayaan bagi disabilitas bertujuan membuat kaum disabilitas lebih mandiri. Kemandirian disabilitas merujuk pada keadaan saat mereka dapat melakukan 
segala aktivitas keseharian untuk memenuhi segala kebutuhan dan keinginannya sendiri tanpa mengharapkan bantuan dari orang lain. Kemandirian ini dicirikan oleh sikap tidak tergantung terhadap orang lain, memiliki kepercayaan diri, berperilaku disiplin, tekun dan gigih, memiliki rasa tanggung jawab, kreatif, mampu mengambil keputusan, melakukan kontrol diri, dan tidak mudah putus asa (Sutardi, 1984 dalam Keumala, 2016).

Kemandirian disabilitas biasanya akan mudah dicapai apabila mereka berdaya secara ekonomi dan sosial. Oleh karena itu, pemberdayaan ekonomi dan sosial merupakan kunci mencapai kemandirian para disabilitas. Pemberdayaan lebih baik lagi jika diprakarsai oleh para disabilitas sendiri, karena akan lebih sesuai dengan kebutuhan, potensi, dan juga aspirasi mereka.

Pemberdayaan ekonomi merujuk pada upaya penguatan kepemilikan individu atau kelompok pada faktor-faktor produksi, penguatan penguasaan distribusi dan pemasaran, penguatan masyarakat untuk mendapatkan gaji/upah yang memadai, dan penguatan masyarakat untuk memperoleh informasi, pengetahuan dan ketrampilan, yang harus dilakukan dengan multiaspek, baik dari masyarakat sendiri, maupun aspek kebijakannya (Hutomo, 2000 dalam Nadzir, 2015). Pemberdayaan sosial menurut (Friedman, 1992 dalam Mardi, 2000) adalah sebuah usaha mendorong rumah tangga lemah untuk memperoleh akses informasi, akses pengetahuan dan keterampilan, akses untuk berpartisipasi dalam organisasi sosial dan akses ke sumber-sumber keuangan. Pada penelitian ini, konsep pemberdayaan sosial dan pemberdayaan ekonomi digunakan sebagai kacamata untuk menganalisis kegiatan yang dilakukan oleh para disabilitas fisik di KBB.

\section{Metode}

Penelitian ini menggunakan metode kualitatif dengan model studi kasus. Kasus yang diamati adalah kegiatan kegiatan produksi kaki tangan palsu di KBB dalam penelitian ini. Teknik pengumpulan data primer dilakukan dengan wawancara mendalam pada para anggota KBB dan beberapa anggota keluarganya; dan partisipasi observasi pada seluruh kegiatan harian yang dilakukan oleh para anggota KBB di bengkel kerja mereka. Teknik analisis data mengikuti prinsip analisis kualitatif. Rekaman wawancara ditranskrip dan dikoding. Tema-tema menonjol yang muncul saat koding disusun dalam tabel tematik dan diinterpretasi guna menggambarkan kegiatan pemberdayaan ekonomi dan sosial di KBB.

\section{Hasil dan Pembahasan}

\section{Profil Kelompok Berani Binangkit}

Kelompok Berani Binangkit (KBB) didirikan pada Maret 2009 oleh lima orang penyandang disabilitas fisik (tangan atau kaki) dan satu orang non-disabilitas. Mereka inilah yang kemudian menjadi pengurus. Sebelum membentuk KBB, mereka pernah tergabung dalam suatu kelompok produksi kaki palsu bernama Tunadaksa Biru Mandiri. Gagasan pendirian KBB dilatarbelakangi oleh pengalaman pribadi empat para pendiri yang merupakan disabel fisik yang kesulitan memperoleh kaki dan tangan palsu dengan harga terjangkau. Harga kaki palsu di pasaran rata-rata mencapai 12 juta rupiah. Mereka berempat bersepakat membuat kelompok produksi kaki dan tangan palsu dengan harga yang lebih terjangkau. KBB juga memiliki misi donasi bagi sesama kaum disabilitas; yaitu dengan cara memberikan kaki atau tangan palsu gratis bagi mereka yang membutuhkan tapi tidak mampu membeli. Setiap keuntungan penjualan 3-4 kaki palsu disisihkan oleh para pendiri untuk modal kaki dan tangan palsu yang akan diberikan secara gratis.

Seiring waktu, anggota KBB tidak hanya berasal dari Kota Bandung saja, tetapi juga dari luar Kota Bandung. Keanggotaan KBB bersifat terbuka, artinya KBB menerima para disabilitas dan non-disabilitas untuk menjadi anggota, dan tidak memiliki keterikatan 
hubungan pekerjaan ${ }^{5}$. Tidak ada syarat-syarat tertentu yang ditetapkan para pengurus bagi calon anggota baru. Para anggota yang belum memiliki keterampilan dalam membuat kaki dan tangan palsu pun tetap diperbolehkan bergabung jika berminat. Para pengurus mengajari para anggota untuk membuat kaki palsu secara bertahap. Menurut Indra, salah seorang pengurus, proses pelatihan membuat kaki dan tangan palsu diawali dari tahap yang ringan, seperti mengoles lem dan memberi busa pada bagian soket hingga menjadi sebuah kaki-tangan palsu. Durasi hingga mendapat keahlian tergantung dari bakat orang tersebut. Biasanya 1 bulan hingga 3 bulan belajar, mereka telah mahir.

Rekruitmen anggota KBB biasanya dilakukan secara lisan. Mayoritas anggota yang saat ini bergabung dengan KBB, pada awalnya merupakan pembeli kaki palsu di KBB. Saat melakukan proses jual-beli pengurus selalu bertanya pada calon pembeli, "Dirumah ngapain? Ada kegiatan gak? Kalo tidak ada kegiatan mau ikut KBB tidak?”. Para pengurus tidak pernah menjanjikan gaji besar dan tetap pada para anggota KBB karena KBB hanya bergantung pada pesanan dan tidak memiliki donatur tetap.

\section{Pemberdayaan Ekonomi di KBB}

Kegiatan pemberdayaan ekonomi di KBB berpusat pada produksi kaki dan tangan palsu. Kegiatan produksi ini mencerminkan keahlian dan keterampilan para pengurus dan anggota kelompok KBB. Anggota KBB mengaku bahwa pendapatan finansial yang mereka peroleh dari penjualan produk kaki -tangan palsu belum cukup bagi kebutuhan sehari-hari keluarga mereka. Namun, mereka tetap merasa bahwa hasil yang kecil tersebut bermanfaat dan membuat mereka merasa berdaya.

Bahan dasar pembuatan kaki-tangan palsu idealnya adalah aluminium, tetapi berhubung para pendiri KBB bermodal pas-pasan, mereka menggunakan PVC. Bahan PVC sebetulnya

\footnotetext{
${ }^{5}$ Seperti kontrak kerja.
}

memiliki kekurangan yaitu tidak fleksibel sehingga sulit dibentuk dan mudah pecah. Pada 2012 KBB mulai menggunakan bahan plat alumunium, selain PVC. Konsekuensinya, harga produk menjadi lebih mahal. Biasanya bahan plat alumunium hanya digunakan untuk pesanan produk dalam jumlah besar. Proses produksi kaki dan tangan palsu berkisar 3-7 hari. Produk memiliki masa garansi 1 bulan sejak pembelian. Jika pembeli merasa ukuran kaki atau tangannya kurang sesuai, ia dapat memperbaikinya kembali di bengkel KBB. Jasa perbaikan kaki dan tangan di luar penggantian komponen, tidak dipungut biaya.

KBB menggunakan media sosial (medsos) online (facebook, intagram, whatsapp) dan website untuk memasarkan produknya. Pemasaran online dilakukan sejak 2009. Saat itu KBB menggunakan media sosial Blackberry Messenger (BBM), mereka menggunakan fitur broadcast message yang berfungsi menyebar informasi mengenai produk KBB ke seluruh daftar kontak pertemanan maupun di dalam grup pertemanan. KBB juga memanfaatkan media sosial facebook untuk pemasaran. Banyak disabilitas dari berbagai daerah yang berkumpul dan membuat grup media sosial, sehingga KBB dengan mudah memperkenalkan produk mereka ke dalam grup tersebut. Pada 2015 KBB membuat Instagram dan mulai memasarkan produk lewat media itu. Pemasaran lewat website tidak terlalu ramai dan kalah dengan media sosial.

Selain memasarkan secara online, KBB juga memasarkan secara offline. Misalnya saat para anggota KBB menghadiri acara-acara bertema kesehatan bagi para disabilitas, mereka juga memperkenalkan produk pada orang yang hadir. Meski jangkauan pemasaran offline tidak seluas pemasaran online tetapi pemasaran offline tidak begitu saja mati. Masih saja ada pembeli yang mengetahui produk KBB melalui informasi langsung dari para anggota KBB ataupun melalui rekanan atau koordinator wilayah di beberapa kota, seperti di Kota 
Lampung dan Aceh. Rekanan ini pada awalnya adalah konsumen KBB. Mereka kemudian menjadi rekanan yang menghubungkan KBB dengan calon pembeli di kota masing-masing.

Sesuai dengan misi mereka, selain berorientasi bisnis, KBB juga berorientasi sosial. Pengurus selalu mempertimbangkan latar belakang kondisi ekonomi calon pembeli dalam menentukan harga. Mereka ingin agar produk mereka tetap terjangkau oleh para disabilitas fisik dan dapat membuat para disabilitas berdaya setelah menggunakan produk mereka.

Bisnis di KBB masih belum teroganisir dengan baik. Pemasukan dan pengeluaran yang tidak tercatat rapi, dan pembukuan masih menggunakan cara konvensional, yaitu dengan mencatat di dalam buku tulis besar. Arsip pendataan hilang dari 2009 hingga 2015. Buku tersebut hilang disaat $\mathrm{KBB}$ berpindah bengkel, tetapi arsip hanya tersisa 2016 dan 2017.

Tanpa pengelolaan bisnis yang baik, para pengurus dan anggota $\mathrm{KBB}$ hanya berpedoman pada menyisihkan profit untuk modal bahan baku pembuatan, listrik, makan, uang kas, kontrakan, dan dana sosial untuk kaki palsu, baru kemudian, mereka membagikan sisa profit penjualan untuk upah. Pembagian profit tersebut berkisar 50\% untuk modal, 25\% untuk listrik, makan, uang kas dan kontrakan, dan 25\% untuk honor. KBB menerapkan sistem tersebut agar tidak terjadi kekurangan biaya produksi, kesulitan untuk membayar kontrak bengkel dan biaya sehari-hari jika tidak ada pesanan yang masuk.

KBB mendapatkan untung sekitar Rp.800.000 hingga Rp.1.000.000 dari sebuah kaki atau tangan palsu setiap bulannya. Jika satu bulan minimal ada 3 pesanan kaki palsu, maka untung bersih kelompok kira-kira berkisar Rp.3.000.000, jika 8 anggota yang ikut memproduksi, maka perorangnya akan mendapatkan Rp.375.000. Selisih upah yang diberikan antara pengurus dan anggota berkisar Rp.50.000 sampai Rp.100.000. Koordinator atau reseller produk KBB akan diberi upah sebesar Rp.200.000 dari setiap pesanan kaki atau tangan. Koordinator biasanya bukan anggota dari KBB. Jumlah anggota yang mengerjakan pesanan kaki tangan palsu mempengaruhi besaran upah yang didapat setiap orang. Penghasilan seorang anggota paling sedikit perbulan berkisar Rp.375.000 dan paling besar penghasilan dapat mencapai Rp.1.500.000 (atau lebih), jika ada banyak pesanan kaki tangan palsu dari donator. Jumlah ini, menurut para anggota KBB, sangat jauh dari cukup.

Para anggota KBB pun berstrategi menghadapi minimnya penghasilan dari kegiatan produksi. Beberapa anggota bekerja sampingan. Anggota yang telah menikah, ikut membantu perekonomian keluarga dengan berjualan, karena hal tersebut mudah untuk dilakukan. Namun, meskipun penghasilan dari KBB hanya kecil dan tidak menentu, para anggota KBB tetap merasa bahwa kegiatan mereka memberdayakan secara ekonomi. Makna pemberdayaan ekonomi yang dimaksud oleh KBB, tidak hanya merujuk pada jumlah penghasilan semata tetapi juga merujuk pada terciptanya kesempatan berkarya yang membuat mereka merasa berdaya. Sebagai penyandang disabilitas fisik, kesulitan aksesibilitas pekerjaan pernah dialami anggota KBB. Oleh karena itu, mereka menganggap KBB sebagai rumah dan wadah mereka dalam berkarya. Mereka pun merasa optimis karena dapat membuktikan kemampuan mereka dalam bekerja.

\section{Pemberdayaan Sosial di KBB}

Sebagian besar anggota KBB merasakan pengalaman berat pasca amputasi tangan atau kaki. Mereka merasa sulit menerima kondisi fisiknya yang tidak lagi lengkap. Namun, bertukar pengalaman hidup dengan anggota lain di KBB dapat menghilangkan rasa pesimis dalam diri mereka sehingga menimbulkan kepercayaan diri. Semenjak mengenal KBB para anggota mulai memiliki pemikiran yang terbuka dan optimis. Bukan hal yang mudah untuk membuka pemikiran disabilitas yang tertutup menjadi terbuka, apalagi bagi 
orang yang baru menjadi disabilitas. Mereka cenderung memiliki sifat tertutup karena malu terhadap lingkungan sosialnya dan perubahan kondisi fisiknya. Di KBB, setiap anggota memiliki kesempatan untuk sharing atau berbagi. Hal tersebut merupakan sesuatu yang penting karena dapat membuka pikiran disabilitas yang masih tertutup. Ujang, salah satu anggota $\mathrm{KBB}$ menyatakan bahwa $\mathrm{KBB}$ merupakan 'rumah sosial' baginya di mana ia menemukan kenyamanan dengan identitas sosial barunya sebagai disabel pasca amputasi akibat kecelakaan. Ia pun merasa nyaman dan tenteram di KBB dan tak lagi merasa murung, kesal, mudah marah, serta tertutup terhadap lingkungan dan orang-orang disekitarnya.

Kelompok-kelompok seperti KBB menjadi lingkungan yang mendukung perbaikan identitas sosial mereka terutama akibat stigma sosial pada disabel. Stigma pada disabilitas sampai sekarang masih sering menanggung stigma di masyarakat karena kondisi fisiknya. Hak-hak dasar pun sulit mereka dapatkan, misalnya pelayanan transportasi publik. Situasi terpinggirkan membuat para anggota $\mathrm{KBB}$ merasa perlu membangun kepercayaan diri serta mencari dukungan sosial untuk membangun kemandirian. Kepercayaan diri berguna bagi disabilitas untuk mengeksplorasi potensi diri, sehingga berani mencoba melakukan yang bermanfaat untuk dirinya sendiri, salah satunya adalah bekerja. Bekerja menjadi salah satu cara anggota KBB untuk membuktikan kemandirian. Selain itu, dukungan sosial dari sesama disabel juga mereka perlukan untuk menguatkan diri dalam merespon stigma.

Gottlib dalam Nurhayati (2012) mendefinisikan dukungan sosial (social support) sebagai sebuah informasi atau nasihat verbal, bantuan nyata, atau tindakan yang diberikan oleh keakraban sosial yang bermanfaat secara emosional dan memiliki efek perilaku tertentu bagi penerima. Dukungan sosial yang muncul antar anggota KBB menjadi faktor yang penting dalam membangun kemandirian mereka. Nyamannya lingkungan sosial KBB memun- gkinkan terciptanya dukungan-dukungan sosial diantara anggota KBB. Dukungan sosial tersebut dapat berupa kesempatan berbagi pengalaman antar anggota KBB dan saling menyemangati agar tidak merasa sendiri dan minder menjadi disabilitas. Dukungan berguna untuk memupuk kepercayaan diri agar mereka mampu mengembangkan potensi yang ada pada dirinya, berani mencari pekerjaan dan mendapatkan penghasilan untuk dirinya sendiri. Bekerja dan berpenghasilan dapat menjadi salah satu pembuktian kemandirian seorang disabilitas, mengingat aksesibilitas dalam bekerja sangat sulit bagi kelompok tersebut .

Sutardi (1984) dalam Keumala (2016) menyebutkan bahwa faktor yang mempengaruhi kemandirian dapat berasal dari dalam individu dan luar individu. Dukungan lingkungan sosial KBB menjadi faktor yang membangun kemandirian disabilitas. Hasil kegiatan pemberdayaan sosial KBB membentuk karakter mandiri. Dadan, salah satu anggota KBB, menyatakan bahwa dirinya telah mandiri, bisa bertindak untuk diri sendiri meskipun hasil dari pengembangan ekonomi belum dapat memenuhi kebutuhan sehari-hari. Pengalaman Dadan membuktikan bahwa pengalaman bekerja dan mendapatkan hasil dari apa yang dikerjakannya dapat membangun kemandirian dalam kehidupannya. Ia juga merasa hidupnya lebih mandiri dan lebih dihargai oleh keluarganya, meskipun penghasilan yang ia dapat dari kegiatan pemberdayaan ekonomi belum mampu menopang hidupnya sepenuhnya.

Kegiatan di KBB membantu para anggota membangun kepercayaan diri dalam menghadapi stigma; dalam berpartisipasi dan beradaptasi di dalam kehidupan masyarakat. Pengalaman Udin dan Ujang, dua anggota KBB, adalah contoh nyata dari hal ini. Udin, pernah ditolak bekerja di sebuah perusahaan karena kondisi disabilitas fisiknya. Padahal, ia telah berhasil melewati serangkaian proses rekrutmen. Namun, mereka tidak menyerah. Di KBB mereka menunjukkan bahwa mereka memang mampu berkarya dengan kondisi fisik mereka 
yang tak lagi lengkap.

Pengalaman Iman, anggota KBB yang juga berprofesi sebagai tukang ojek, juga menunjukkan betapa kegiatan di KBB sangat membantu para anggotanya membangun sikap tabah dan tangguh dalam menghadapi stigma.

Iman seringkali menemui beberapa calon penumpang yang tidak percaya pada kemampuannya mengendara karena ia tak lagi memiliki kaki. Namun, ia membuktikan pada para penumpangnya bahwa ia mampu. Sikap percaya diri itu diperoleh Iman setelah bergaul dengan teman-temannya di KBB. Ia melihat bahwa semua temannya di KBB sangat mandiri dan percaya diri. Hal ini memicunya untuk menumbuhkan sikap yang sama.

Para anggota KBB juga membangun kepedulian kepada rekan-rekan disabilitas yang menjadi gepeng. Gepeng adalah status sosial dengan stigma tinggi di masyarakat. Banyaknya gepeng di masyarakat, telah menggiring masyarakat untuk membentuk anggapan bahwa "kaum disabilitas perlu dikasihani". Para anggota KBB beranggapan bahwa mereka perlu menghapus stigma itu. Namun, mereka tidak bisa berjalan sendiri dalam menghapus citra negatif identitas disabilitas, sebab hal tersebut membutuhkan sinergi dari banyak stakeholder. Para anggota KBB menyadari bahwa kaum disabilitas yang menjadi gepeng belum dapat membangun kepercayaan diri dan menggali potensi dirinya

Arman, salah satu anggota KBB, menuturkan bahwa, seharusnya para penyandang disabilitas tidak perlu merasa bahwa kondisi fisik mereka menjadikan hidup mereka terbatas. Menurutnya, disabilitas justru harus menunjukan kemandirian mereka dalam bekerja. Arman mengakui bahwa rasa percaya dirinya terbentuk ketika ia masuk KBB. Ia menyebut bahwa ia tidak ada waktu untuk mengasihani diri sendiri. Ia hanya berpikir untuk dapat bekerja

produktif meskipun ia seorang disabilitas. Ia bersikeras bahwa beragam cara patut dicoba dan dikerjakan oleh para penyandang disabilitas, selagi mampu dan menghasilkan. Banyak jalan yang dapat ditempuh ketika disabilitas ingin bekerja dengan laik dan tidak ke jalanan, dan tidak merusak citra disabilitas.

Para anggota KBB menyatakan bahwa para penyandang disabilitas memiliki rasa minder dan rasa putus asa tetapi di KBB mereka memupus sikap tersebut. Mereka berpedoman bahwa penyandang disabilitas harus memiliki pemikiran yang terbuka dan luas. Mereka juga menegaskan bahwa penyandang disabillitas yang memutuskan mencari nafkah dengan turun ke jalan dapat memberikan dampak negatif bagi para penyandang disabilitas lain. Sebab, hal itu akan memperkuat pandangan negatif masyarakat terhadap para penyandang disabilitas; dianggap tak berdaya dan lemah.

Selain membentuk sikap mandiri dan percaya diri, kegiatan di KKB menciptakan ruang yang nyaman dan aman bagi para anggotanya. Sebab, setiap anggota KBB memiliki ikatan sosial yang sangat kuat. Mereka selalu berupaya bekerjasama dan menjaga komunikasi agar produksi kaki tangan palsu berjalan dengan baik. Anggota yang tidak berkontribusi secara langsung dalam proses produksi kaki tangan palsu tetap berkontribusi dalam hal lain, misal pemasaran produk. Partisipasi aktif para anggota menghasilkan ikatan emosional dan sosial yang kuat diantara mereka, dan membentuk modal sosial yang kuat.

Keakraban tampak menonjol diantara para anggota. Mereka tidak mengenal jarak usia antar anggota (senior-junior/tua-muda) dan saling menghormati serta menghargai. Bahkan mereka merasa sebagai satu keluarga. Keakraban mereka tampak dalam cara mereka berkomunikasi yang khas $^{6}$. Anggota KBB biasa berkomunikasi dengan menggunakan bahasa slang ${ }^{7}$, bahasa Sunda kasar, dan guyo-

\footnotetext{
${ }^{6}$ Berguyon menggunakan serapan fisik/menggunakan nada tinggi/sulit serius dalam menanggapi lawan bicara

${ }^{7}$ Kata-kata non-standar yang informal, yang disusun secara khas. Kata-kata slang bukan terdapat pada golongan terpelajar, tetapi juga pada semua lapisan masyarakat.
} 
nan. Guyonan anggota KBB sering bersumber pada kondisi fisik mereka. Namun, tidak ada di antara mereka yang merasa tersinggung atau marah apabila ada anggota yang melontarkan guyonan demikian. Guyonan salah satu anggota KBB bernama Koswara yang dilontarkan pada temannya, Drajad, yang tak lagi memiliki kedua kaki, adalah salah satu guyonan yang bersumber pada kekurangan fisik:

"Anjir, semalem pas gempa si Drajad ge reuwas (kaget), ngibrit kabeh (lari semua), Drajad jadi cepet kitu euy lumpatna (cepat larinya) hahaha" (Ucapan Koswara, anggota KBB, 24 Januari 2018)

Guyonan semacam itu seringkali terlontar di antara anggota KBB. Orang yang baru pertama kali mengenal dan ikut berkomunikasi dengan anggota KBB akan menganggap bahwa guyonan tersebut melecehkan. Namun, bagi para anggota guyonan demikian sudah sangat biasa bahkan menandakan keakraban. Anggota KBB tetap memperhatikan guyonan mereka agar tetap pada batas kesopanan dengan lawan bicara.

Di antara anggota KBB tidak ada sapaan yang menujukkan senioritas. Sapaan "Kang" (kakak) tidak pernah terdengar di antara mereka, dan semua anggota KBB saling memanggil dengan sebutan nama. Bahasa yang digunakan para anggota KBB untuk berkomunikasi adalah bahasa Sunda. Misal kata "aing" (Bahasa digunakan untuk menyebut diri sendiri dan kata "maneh" menyebut lawan bicara. Kata: 'maneh' dalam bahasa Sunda seringkali digunakan sebagai sapaan pada orang yang kedudukannya setara secara usia. Penggunaan kata kasar lain seperti "anjir" (pelesetan kata 'anjing') dan "blok" (goblok = bodoh) yang merupakan bahasa kasar menjadi hal biasa bagi para anggota KBB. Misal, ucapan Jojon, anggota KBB dengan Dodot (anggota KBB lainnya):

“...Duh, aing teh kadieu mararacet. Ke sini macet, ke sana macet, itu naik motor.
Parah pisan mun libur kieu teh. Maneh baru sampe Dot?...."

(“....Duh, saya ke sini (bengkel KBB) pada macet. Ke sini macet, ke sana macet, itu naik motor. Parah banget kalo libur gini tuh. Kamu baru sampai Dot?...." (Jojon, 1 Oktober 2017)

Ketika berkomunikasi, anggota $\mathrm{KBB}$ juga sering menggunakan nada yang tinggi sehingga terkesan seperti orang sedang marah atau ingin menjatuhkan lawan bicara, terutama saat bercanda. Namun, pada dasarnya hal itu hanyalah sebagai bagian dari guyonan. Misal, ucapan Dodo pada salah satu anggota KBB saat membicarakan, anggota lain (Dadan) yang menurut Dodo lambat bekerja. Dodo menggunakan nada tinggi saat berbicara dengan temannya mengenai Dadan, seolah-olah terkesan ingin memecat Dadan (padahal Dodo hanya bercanda :

\section{"Kumaha ini teh?! Anu kamari acan di- gawekeun?! Keluarkeun weh kitu yah si Dadan teh? ( Oju, 12 September 2017) ( Dodo, 12 September 2017) \\ ("Bagaimana sih ini?! Yang kemarin be- lum dikerjakan?! Keluarkan (pecat) saja gitu yah si Dadan?}

Selain melalui cara verbal, keakraban juga tindakan, misalnya tingkah laku iseng dan makan bersama. Keisengan di antara para anggota bukan dimaksudkan untuk menghina atau merendahkan satu sama lain, tetapi sebagai ekspresi keakraban diantara mereka. Amin, salah satu anggota menuturkan:

"Iya kalo lagi pada kumpul pada iseng, kadang kaki diumpetin, kadang salah pakai (kaki palsu), si Drajad mah gede, ketawan. Harus kuat mental, silih hina kalo (saling hina/menjatuhkan) orang mah udah pundung, saya mah udah siap weh." (Amin, 1 November 2017).

Makan bersama dilakukan oleh para anggota setiap saat, baik makan siang maupun makan 
malam. Mereka memasak nasi sendiri dan membeli lauk sederhana dari warung. Makan bersama merupakan bagian dari strategi mereka menghemat biaya makan. Uang sebesar Rp.20.000Rp.30.000 dibelikan lauk pauk yang dapat dikonsumsi 3-5 orang anggota. Jumlah ini sangat hemat dibandingkan dengan makan sendiri, sebab biaya yang dikeluarkan untuk seporsi makan per orang dapat mencapai Rp.10.000-Rp.15.000.

Anggota KBB yang telah bekerja di tempat lain (selain produksi kaki tangan palsu) tetap memelihara hubungan baik dengan kelompok KBB. Ikatan emosional yang terbangun antara anggota sangat kuat sehingga saat mereka sudah tak lagi beraktivitas di KBB pun tetap mengenang masa-masa mereka berada di sana.

Kegiatan di KBB memberikan suasana baru yang mendorong para anggota untuk membangun dan memperbaiki citra negatif identitas sosial mereka sebagai disabel. Misal, pada kasus Koswara, salah satu anggota; KBB merupakan tempatnya untuk menyegarkan kembali kehidupan sosialnya sebagai disabel. Sebelum bergabung dengan KBB, ia bekerja sebagai buruh pabrik konveksi. Seringkali ia merasakan jenuh dalam bekerja sehingga sesekali ia menghilangkan kejenuhannya dengan berkunjung ke KBB. Lambat laun, ia justru memutuskan meninggalkan pekerjaannya di pabrik dan bergabung di KBB. Penghasilan Koswara di pabrik lebih besar daripada penghasilannya di KBB. Namun, ia membutuhkan lingkungan sosial yang nyaman bagi dirinya yang disabel. Di KBB ia merasa menemukan wadah yang tepat untuk hal itu.

KBB terbentuk sebagai sebuah struktur organisasi yang bersifat vertikal, tetapi KBB menerapkan interaksi yang dilakukan horizontal dan informal. Ikatan emosional yang kuat menimbulkan suasana "santai tapi serius".

Salah satu produk dari kegiatan di KBB adalah terciptanya modal sosial diantara para anggotanya. Putnam dalam Syahra
(2003) mendefinisikan modal sosial sebagai seperangkat hubungan horizontal antara individu dalam jaringan keterikatan sosial yang diatur oleh norma-norma yang menentukan produktivitas suatu kelompok masyarakat atau komunitas. Ada dua hal yang merupakan asumsi dasar dari konsep model sosial, yakni 1) adanya jaringan hubungan dengan norma-norma yang terkait, dan 2) keduanya saling mendukung guna mencapai keberhasilan di bidang ekonomi bagi orang-orang yang termasuk dalam jaringan tersebut.

Melemahnya produksi kaki dan tangan palsu dapat melemahkan kondisi ekonomi para anggota $\mathrm{KBB}$, tetapi kondisi tersebut membentuk ikatan emosional yang kuat di antara mereka. Para anggota dilatih untuk mandiri dalam kesederhanaan. Mereka dituntut untuk berbagi ke sesama anggota dan orang lain, meski pun tidak memiliki daya yang besar. Aktivitas yang biasa mereka lakukan adalah kegiatan makan siang yang mereka lakukan bersama-sama, membeli lauk dari warung atau membuat sendiri di dapur kemudian di bagi rata kepada seluruh anggota yang berada di bengkel KBB. Pengurus wajib menyisihkan biaya hidup di bengkel KBB dari kegiatan produksi.

Membuat kopi dan membawanya ke ruang tamu bukanlah aktivitas yang mudah, tetapi hal itu dapat dilakukan sendiri oleh anggota KBB. Hal itu membuat mereka merasa mampu menjalankan aktivitas yang normal bagi kebanyakan orang. Selain itu aktivitas kecil mengajarkan pada mereka untuk membangun sikap mandiri sebagai disabilitas secara sosial, membiasakan diri menjadi disabilitas di luar lingkungan sosial KBB.

KBB memberikan pengalaman kerja yang dapat dirasakan oleh kaum difabilitas sehingga mereka dapat merasakan pekerjaan; bagaimana menuntaskan suatu pekerjaan, bagaimana membangun bekerja sama, dan mendapatkan hasil dari apa yang dikerjakan. Setelah anggota mampu berkarya, mereka merasakan dan menyadari bahwa dirinya memiliki kapabilitas dalam menghadapi pekerjaan; hal ini kemudi- 
an menumbuhkan rasa percaya diri mereka. Tidak hanya percaya diri dalam bekerja, tetapi rasa percaya diri dalam bermasyarakat.

Bagi para angota $\mathrm{KBB}$, bekerja adalah cerminan dari kemandirian mereka karena dapat menafkahi kehidupannya sendiri. Namun, bagi penyandang disabilitas, pekerjaan merupakan ranah yang sulit diakses karena penyandang disabilitas masih diragukan kemampuan fisiknya dalam bekerja. Para penyedia pekerjaan belum dapat menerima secara langsung kemampuan penyandang disabilitas dalam bekerja. Akibatnya, penyandang disabilitas sulit mendapatkan pekerjaan. Padahal kesempatan bekerja akan berguna bagi penyandang disabilitas untuk meyakinkan khalayak, bahwa mereka mampu bekerja atau melakukan kegiatan seperti orang bukan disabilitas. Oleh karena itu, banyak penyandang disabilitas yang bekerja pada sektor informal karena tidak mampu memenuhi kualifikasi untuk memasuki sebuah pekerjaan formal. Lebih buruknya, disabilitas menjadi gepeng ${ }^{8}$. Gepeng adalah salah satu kenyataan yang menunjukkan bahwa penyandang disabilitas belum memiliki kepercayaan diri dan belum mau menggali potensi diri serta terpaksa mengorbankan harga dirinya untuk dieksploitasi oleh oknum tertentu.

Ujang, salah satu anggota KBB, pernah mengalami stigmatisasi di dunia kerja. Namun, ia memiliki kepribadian yang kuat sehingga ia mampu terus berjuang mendapatkan pekerjaan. Kepercayaan diri yang ia bentuk banyak dipengaruhi oleh partisipasinya di KBB. Kepercayaan diri dipupuk oleh anggota dengan lingkungan sosial KBB. Ia merasa termotivasi karena perasaan senasib dan karena dirinya memiliki rekan-rekan (di KBB) yang semangat dalam bekerja. Ia juga menuturkan bahwa sebenarnya ia merupakan pribadi yang tertutup pada lingkungan sosialnya pasca kakinya diamputasi; bahkan nyaris bunuh diri karena putus asa. Namun, di KBB ia dapat membuka pikirannya dan tidak merasa sendiri sebagai penyandang disabilitas. Ia

\footnotetext{
${ }^{8}$ Gepeng akronim dari gelandangan dan pengemis
}

menyadari bahwa masih ada orang lain yang keadaannya lebih "buruk" darinya. Hal itu membuat ia menjadi lebih semangat menjalani hidup.

Paparan di atas menunjukkan bahwa kegiatan di KBB mendorong tumbuhnya kepercayaan diri di kalangan anggotanya. hal ini dapat membantu mereka memiliki identitas sosial yang positif di masyarakat dan dapat mendorong mereka untuk mengeksplorasi kemampuannya dalam berkarya utuk mendapatkan sumber penghidupan. Ikatan emosional diantara para anggota, telah menghasilkan modal sosial yang kuat pula.

\section{Simpulan}

KBB melakukan dua kegiatan yang menghasilkan pemberdayaan anggotanya dalam dua hal yaitu ekonomi dan sosial. Proses pemberdayaan ekonomi tampak dalam kegiatan produksi kaki dan tangan palsu, sedangkan, pemberdayaan sosial tampak dalam sikap dan tindakan percaya diri yang terbentuk di antara para anggota, dilakukan.

Hasil kegiatan pemberdayaan ekonomi,belum dapat menopang kehidupan sehari-hari para anggota dan keluarganya. Penghasilan yang didapat para anggota dari hasil penjualan produk di KBB tidak menentu dan jumlahnya sangat kecil. Anggota KBB melakukan beberapa strategi agar kebutuhannya tetap terpenuhi. Diantaranya mencari pekerjaan tambahan. Bagi anggota KBB yang telah menikah, pasangan mereka ikut berkontribusi. Kontribusi istri berkisar 30-50\% dari pemenuhan kebutuhan ekonomi rumah tangga. Oleh karena itu, kegiatan produksi kaki tangan palsu tidak dapat dijadikan penghasilan utama, melainkan penghasilan sekunder.

Kegiatan pemberdayaan ekonomi yang dilakukan oleh KBB memang belum menunjukan hasil yang maksimal. Tetapi hasil pemberdayaan sosial justru lebih menunjukan hasil positif. Hasil pemberdayaan sosial di KBB dapat dilihat dari kemandirian disabilitas, terbentuknya 
ikatan sosial antar anggota dan terbentuknya pola interaksi sosial yang khas dan ikatan sosial yang kuat diantara para anggota.

KBB menjadi lingkungan sosial yang baik bagi disabilitas untuk membentuk kepercayaan dirinya. Anggota-anggotanya membangun ikatan emosional melalui komunikasi yang informal. Karena memiliki latar belakang yang sama, hubungan yang dibangun oleh mereka menjadi semakin akrab. Hubungan semacam ini dapat membentuk pemikiran penyandang disabilitas menjadi lebih terbuka; mereka lebih dapat menerima keadaan, dan mampu mengalihkan pikiran ke dalam hal yang lebih produktif dan serta kesempatan bagi mereka untuk menggali potensi diri.

\section{Daftar Pustaka}

Corrigan, P. (2004). How Stigma Interferes With Mental Health Care. American Psychologist, 15 (7) Hal: 614-625.

Gaffara, C; Riyono, B; Setyawati, D. (2017). Peran Karang Taruna Dalam Pemberdayaan Penyandang Disabilitas Di Desa Karangpatihan, Kabupaten Ponorogo Dan Implikasinya Terhadap Ketahanan Ekonomi Keluarga. Jurnal Ketahanan Nasional, 23 (1) Hal: 37-48.

Goffman, E. (1963). Stigma Notes on the Management of Spoiled Identity. London: Pinguin.

Luthfiana, Y; W. Lestari. (2012). Orang Kolok dan Orang Inget: Studi Kasus tentang Inklusi Sosial Disabilitas Ketulian dan Penanganan Kesehatan Indera di Desa Bengkala Buleleng, Bali. Buletin Penelitian Sistem Kesehatan, Vol 15(4)

Rodiah, MM. (2014). Pemberdayaan kelompok Disabilitas Melalui Kegiatan Ketrampilan Handicraft dan Woodwork Di Yayasan Wisma Cheshire Jakarta Selatan. Repository.uijkt. ac.ud

Keumala, C. R.N (2016). Pengaruh Konsep Desain Universal Terhadap Tingkat Kemandirian Disabilitas : Studi Kasus Masjid UIN Sunan Kalijaga dan Masjid Kampus Univer- sitas Gadjah Mada. INKLUSI: Journal of Disability Studies, III, 19-39.

Mujimin. (2007). Penyediaan Fasilitas Publik yang Manusiawi Bagi Aksesibilitas Disabilitas . Jurnal Dinamika Pendidikan, Hal: 60-75.

Muntaz, A; Rahmawati, A. (2015). Proses Adaptasi Sosial Siswa Disabilitas dengan Siswa Non-Disabilitas. Ilmu Kesejahteraan Sosial Universitas Jember Jurnal, Edisi April. Hal: 1-14.

Nadzir, M. 2015. Membangun Pemberdayaan Ekonomi di Pesantren. Jurnal Economica, Vol 6 (1): 37-56.

Rahman, F. (2008). Evaluasi Partisipatoris Terhadap Pelatihan Pendampingan Komunitas Disabilitas Di Daerah Istimewa Yogyakarta. Jurnal Penelitian Humaniora. Hal: $1-22$.

Sinulingga, I. N. (2015). Keindahan dalam Disabilitas: Sebuah Konstruksi Teologi Disabilitas Intelektual. Indonesian Journal of Theology, 35-60.

Siska; Sudardjo; Purnamaningsih, E. H. (2003). Kepercayaan Diri dan Kecemasan Komunikasi Interpersonal Pada Mahasiswa. Jurnal Psikologi,, Hal: 67-71.

Utami, N. W. (2015). Gelap dalam Gemerlap: Gelapnya Akses Informasi Bagi Disabilitas dalam Gemerlap Era Digitalisasi. Channel, Hal: 41-49.

Utomo, S. (2015, Juni 26). Solopos.com. Retrieved from RUU Penyandang Disabilitas: Istilah DIsabilitas dan Difababilitas Sempat Diperdebatkan: http://www.solopos. com/2015/05/26/ruu-penyandang-disabilitas-istilah-disabilitas-dan-difabilitas-sempat-diperdebatkan-608218

Widiantoro, W: Wartono: Sinta, A. (2016)). Pemberdayaan Warga Diabel Kunci Sukses Penggalian. Prosiding Seminar Nasional Psikologi "Aktualisasi Potensi Anak Bangsa Menuju Indonesia Emas. Hal: 5561. 
